\title{
ЦИВІЛЬНО-ПРАВОВІ АСПЕКТИ УКЛАДАННЯ ДОГОВОРУ ПРО НАДАННЯ ОСВІТНІХ ПОСЛУГ
}

\author{
CIVIL LEGAL ASPECTS OF THE CONTRACT \\ OF EDUCATION SERVICES
}

\author{
Кравець Т.С., студентка III курсу \\ Інститут прокуратури та кримінальної юстиції \\ Начіонального юридичного університету імені Ярослава Мудрого
}

\begin{abstract}
У статті розглянуто питання, присвячені договірному регулюванню надання освітніх послуг. Підкреслюється, що найпопулярнішою формою забезпечення освіти $є$ договір. Зазначається, що чинне законодавство України не визначає поняття договору про надання освітніх послуг, а це, відповідно, створює багато труднощів у практичній діяльності вищих закладів освіти. На основі аналізу поглядів науковців визначено поняття договору про надання освітніх послуг. Завершена юридична характеристика договору про надання освітніх послуг, з'ясовано його особливості. Акцентовано увагу на тому, що договір про надання освітніх послуг належить до публічних договорів та договорів про приєднання, тому підрядник зобов'язаний укласти договір, якщо він може надати таку освіту, а замовник приєднується до запропонованих умов договору в цілому. Аргументовано, що особливістю договору про надання освітніх послуг, на відміну від надання інших послуг, $є$ неможливість гарантування виконавцю досягнення високого результату його діяльності, оскільки цей результат залежить не лише від виконавця, а й від студента, його здібностей, уваги та старанності. Проаналізовано правовий статус підрядника та замовника договору про надання освітніх послуг. Зазначено, що укладанню договору про надання освітніх послуг, як правило, передує низка юридичних фактів, зокрема: конкурс (підбір абітурієнтів), підписання договору, видача наказу про зарахування студента на навчання. Розкрито істотні умови договору про надання освітніх послуг, зокрема поняття освітньої послуги, що є предметом договору. Підкреслюється, що поряд із предметом договору про надання освітніх послуг вагоме значення має їх якість. Зроблено висновок про те, що шлях закріплення істотних умов договору про надання освітніх послуг у підзаконному правовому акті, а не в законі $\epsilon$ неправильним, а тому вони повинні бути закріплені в законі, враховуючи його значення для широкого кола осіб.
\end{abstract}

Ключові слова: договір, освітні послуги, надання освітніх послуг, предмет договору, істотні умови, виконавець, замовник освітніх послуг.

The article deals with the contractual regulation of the provision of educational services. It is emphasized that the most popular form of educational provision is contract. It is stated that the current legislation of Ukraine does not define the concept of a contract for the provision of educational services, and this, accordingly, creates many difficulties in the practical activity of higher education institutions. Based on the analysis of the views of scientists, the concept of a contract for the provision of educational services is defined. The legal characterization of the contract on the provision of educational services is completed and its features are clarified. Emphasis is placed on the fact that the contract for the provision of educational services belongs to public contracts and contracts of accession, so the contractor is obliged to conclude the contract if he is able to provide such educational service, and the customer joins the proposed terms of the contract as a whole. It is justified that the peculiarity of the contract on the provision of educational services, unlike the provision of other services, is the inability to guarantee the performer the achievement of a high result of his activity, since he (the result) depends not only on the performer, but on the student, on his ability, attention, diligence, diligence. The legal status of the contractor and the customer of the educational services contract is analyzed. It is noted that the conclusion of the contract on the provision of educational services, as a rule, is preceded by a number of legal facts, in particular they include: competition (selection of entrants), signing a contract, issuance of an order for enrollment of a student for study. The essential terms of the contract on the provision of educational services are covered, in particular the concept of educational service that is the subject of the contract is revealed. It is emphasized that, along with the subject of the contract on the provision of educational services, their quality is of great importance. It is concluded that the enshrining of the essential terms of a contract for the provision of educational services in a subordinate legal act, and not in the law is incorrect, and therefore they should be enshrined in the law, given its importance for a wide range of persons.

Key words: contract, educational services, provision of educational services, subject of the contract, essential conditions, contractor, customer of educational services.

Постановка проблеми. Освіта $є$ основою інтелектуального, духовного й культурного розвитку особистості, іiі успішної соціалізації, економічного добробуту, а також запорукою процвітання суспільства й держави. Право на освіту передбачене ст. 53 Конституції України, тобто є досить важливим соціальним правом людини. Нині освіта переважно починає орієнтуватися на задоволення особистих потреб людини, пов'язаних із ії культурним розвитком і набуттям нових знань. В умовах прогресивного розвитку ринкових відносин сферу освітніх послуг також було включено до їх складу. До того ж постійне реформування системи освіти тягне за собою зміни в наданні освітніх послуг. Тому однією 3 тенденцій розвитку освітньої діяльності в сучасних умовах $€$ розширення платних послуг, що стосується не лише приватних, а й державних і комунальних закладів освіти. Зовнішньою формою вираження відносин між закладом вищої освіти та громадянином, який прагне отримати вищу освіту, є договір про надання освітніх послуг. Однак виникає чимало дискусій стосовно природи цього договору: одні вчені вважають його цивільно-правовим, а інші відносять його до категорії адміністративних договорів. Таким чином, зазначене свідчить про актуальність обраної теми.
Мета дослідження полягає у визначенні цивільноправових аспектів укладання договору про надання освітніх послуг.

Аналіз останніх досліджень і публікацій. Окремі проблеми договірного регулювання надання освітніх послуг досліджували М.П. Баб'юк, Л.М. Волчанська, І.О. Голоденко, Я.О. Горинь, Б.В. Деревянко, К.А. Карчевський, О.В. Розгон, Н.В. Федорченко та інші.

Виклад основного матеріалу. Наразі у правовому просторі триває дискусія щодо природи договору про надання освітніх послуг. Переважає твердження, що договір про надання освітніх послуг має цивільно-правову природу, хоча $є$ й інша думка: цей договір належить до адміністративно-правових за своєю сутністю, адже однією зі сторін договору $є$ заклад освіти, наділений публічно-правовим характером. Проте ми згодні 3 першою позицією, а тому стаття буде присвячена аналізу виключно цивільно-правових аспектів договору надання освітніх послуг.

Відповідно до чинного законодавства, яке регулює надання освітніх послуг в Україні (це, зокрема, закони України «Про освіту» [1] та «Про вищу освіту» [2]), і положень Порядку надання платних послуг [3] підставою 
для надання конкретного виду платних послуг є договір (контракт) із фізичною або юридичною особою, у якому визначаються порядок надання послуги, розмір та терміни оплати наданої послуги [4].

Згідно із ч. 1 ст. 626 Цивільного кодексу України (далі ЦК України) договором є домовленість двох або більше сторін, спрямована на встановлення, зміну чи припинення цивільних прав та обов'язків [5].

За договором про надання послуг одна сторона (виконавець) зобов'язується за завданням другої сторони (замовника) надати послугу, яка споживається у процесі вчинення певної дії або здійснення певної діяльності, а замовник зобов'язується оплатити виконавцеві зазначену послугу, якщо інше не встановлено договором (ч. 1 ст. 901 ЦК України) [5].

Щодо поняття договору про надання освітніх послуг, то чинне законодавство України не містить його визначення, що, відповідно, викликає чимало труднощів у практичній діяльності вищих навчальних закладів [6, с. 89].

Зауважимо, що нині українська юридична література не надає єдине тлумачення поняття договору про надання освітніх послуг.

Так, К.А. Карчевський стверджує, що у вітчизняній юридичній літературі під договором про надання платних освітніх послуг розуміють домовленість, згідно 3 якою виконавець зобов'язується надати освітні послуги шляхом здійснення заходів навчального, методичного, організаційного та матеріально-технічного характеру, обсяг, зміст і характер яких повинні відповідати державним стандартам освіти та/або домовленості сторін, і в передбачених законодавством випадках підтвердити рівень та обсяг отриманих замовником знань; натомість замовник зобов' язується брати особисту й активну участь у споживанні наданих послуг та оплатити зазначену діяльність $[7$, c. 4]. Тобто дослідник під об'єктом зобов'язань закладу освіти розуміє виконання навчальної програми, яка повинна відповідати встановленим законодавством вимогам, або здійснення заходів навчального, методичного, організаційного та матеріально-технічного характеру. При цьому на особу, яка навчається, покладається обов'язок «сприяти належному виконанню послуги замовником» та «брати активну участь у споживанні наданих послуг» [8, с. 212].

Своєю чергою М.П. Баб'юк розглядає договір про надання освітніх послуг як домовленість, згідно з якою виконавець зобов'язується надати якісні освітні послуги шляхом вжиття заходів навчального, наукового, методичного, організаційного та матеріально-технічного характеру, обсяг, зміст і характер яких повинні відповідати державним стандартам освіти та/або домовленості між сторонами, а замовник зобов'язується належним чином споживати надані послуги та, якщо це передбачено домовленістю між сторонами, оплатити надану послугу [9, c. 105].

На думку Л.М. Волчанської, договір про надання освітніх послуг - це допустима законом письмова угода освітнього закладу зі студентом або слухачем про встановлення правовідносин, у які вони вступають із метою здобуття вищої освіти [10, с. 265].

3 огляду на вищезазначене під договором про надання освітніх послуг варто розуміти домовленість, згідно з якою одна сторона (виконавець) зобов'язується за завданням другої сторони (замовника) надати освітні послуги, що повинні відповідати державним стандартам освіти та/ або домовленості сторін, а замовник зобов'язується споживати надані послуги та оплатити їх виконавцеві, якщо інше не встановлено договором чи законом.

На нашу думку, змістом послуг для набуття вищої освіти є дії навчального закладу з передання (поширення) інформації, яка відповідає вимогам (стандартам), встановленим законодавством. Що стосується освітніх оплатних послуг, то це $є$ інформаційним продуктом, ресурсом, що є товаром [8, с. 212-213]. О.В. Кохановська констатує, що інформацію можна розуміти як інформаційний продукт, ресурс, документ, тобто об'єкт, який може бути інформаційним товаром і предметом будь-яких правочинів, з урахуванням особливостей та специфіки його як особливого об'єкта [12, с. 8].

Як зазначає Л.М. Волчанська, особливістю договору про надання освітніх послуг, на відміну від надання інших послуг, є неможливість гарантування виконавцем досягнення високого результату своєї діяльності, оскільки він (результат) залежить не тільки від виконавця, а й від самої особи, яка навчається, від ії спроможності, уваги, старання, працелюбності $[10$, с. 4]. Так, у разі невідповідності знань, навичок і вмінь встановленим законодавством вимогам студент може не отримати документ про вищу освіту, а договір про надання освітніх послуг може бути достроково розірваний за ініціативою навчального закладу [11, с. 70].

Договір про надання освітніх послуг за моментом укладання $є$ консенсуальним, оскільки вважається укладеним із моменту досягнення згоди між сторонами щодо всіх істотних умов договору. Таким чином, права й обов'язки виникають у сторін у момент досягнення згоди між замовником освітньої послуги та ії виконавцем. Однак оплата послуг у цьому договорі належить до стадії виконання, а не виникнення договору про надання освітніх послуг [6, c. 90].

Згідно зі ст. 638 ЦК України договір вважається укладеним, якщо сторони в належній формі досягли згоди з усіх істотних умов договору. Істотними умовами договору є умови про предмет договору, умови, що визначені законом як істотні або є необхідними для договорів цього виду, а також умови, щодо яких за заявою хоча б однієї зі сторін має бути досягнуто згоди [5].

За наявності зустрічного майнового задоволення договір про надання освітніх послуг, як правило, $є$ оплатним для замовника (споживача цих послуг), проте якщо освітні послуги надаються навчальним закладом за рахунок бюджетних коштів, то для замовника він $є$ безоплатним. Договір про надання освітніх послуг є двостороннім (взаємним), оскільки як виконавець, так і замовник наділені взаємними правами й обов'язками. Зокрема, навчальний заклад (виконавець) зобов'язаний надати освітні послуги, які повинні відповідати державним стандартам освіти, інформувати замовника (одержувача) про правила та вимоги щодо організації надання освітньої послуги, її якість і зміст, про його права й обов'язки під час надання та отримання зазначеної послуги тощо. Своєю чергою замовник зобов'язаний своєчасно вносити плату за освітню послугу в розмірах і в порядку, що встановлені цим договором.

Необхідно зазначити, що в договорі про надання освітніх послуг $є$ елементи публічного договору. 3 огляду на положення ст. 633 ЦК України договір $є$ публічним, якщо одна сторона - підприємець - взяла на себе обов'язок здійснювати продаж товарів, виконання робіт або надання послуг кожному, хто до неї звернеться. Умови публічного договору встановлюються однаковими для всіх споживачів, крім тих, кому за законом надані відповідні пільги [5]. Так, замовник освітніх послуг отримує єдиний для всіх у цьому навчальному закладі обсяг прав та обов'язків, а здобуття освітнього рівня підтверджується державою $[4$, c. 102$]$

О.В. Розгон вважає, що договір про надання освітніх послуг містить елементи публічного договору. Так, вищий навчальний заклад шляхом оферти заздалегідь повідомляє потенційним контрагентам відомості про ліцензію на здійснення освітньої діяльності, про акредитацію та атестацію, інформує про перелік, правила, процедури, строки й форму вступних випробувань, порядок оскарження їхніх результатів тощо. Акцептом вступника вважається 
особисте подання ним заяви про прийом і відповідних документів, письмове підтвердження ознайомлення з умовами вступу й навчання та письмова згода на участь у процедурі допуску до вищої освіти [4, с. 102].

Договір про надання освітніх послуг можна віднести до договорів, які укладаються вільно; також його можна віднести до договорів приєднання [6, с. 91]. Відповідно до ст. 634 ЦК України договором приєднання є договір, умови якого встановлені однією зі сторін у формулярах або інших стандартних формах; він може бути укладений лише шляхом приєднання другої сторони до запропонованого договору в цілому. Друга сторона не може запропонувати свої умови договору [5]. Договір про надання освітніх послуг є договором приєднання, адже замовник (споживач) освітніх послуг приєднується до існуючих правовідносин та погоджується на встановлений для всіх здобувачів освіти рівний обсяг обов'язків і прав [4, с. 105]

Варто зазначити, що Постановою Кабінету Міністрів України від 19 серпня 2015 р. № 634 затверджено Типовий договір про надання освітніх послуг між вищим навчальним закладом і фізичною (юридичною) особою [13]. Розроблення таких форм договору має сприяти захисту прав особи, яка навчається, зниженню ризику порушення іiі прав, оскільки договори містять усі обов'язкові умови, передбачені законодавством [6, с. 91].

3 огляду на те, що договір про надання освітніх послуг належить до публічних договорів (заклад вищої освіти зобов'язаний укласти договір, якщо він у змозі надати таку освітню послугу) та договорів приєднання (у контрагентів закладу вищої освіти є лише право приєднатися до запропонованих умов договору в цілому), особа, яка навчається, приєднується до умов договору $[8$, c. 214$]$

Укладанню договору про надання освітніх послуг, як правило, передує низка юридичних фактів, зокрема успішне проходження вступних випробувань і проходження конкурсу. На думку О.В. Розгон, за своїм змістом договір між вступником та вищим навчальним закладом $\epsilon$ правочином щодо надання освітніх послуг із відкладеною умовою (попереднім договором, передбаченим ст. 635 ЦК України). Відкладеною умовою в цьому разі вважається успішне проходження конкурсу. Однак учена наголошує на тому, що до такого договору, на відміну від юридичного змісту попереднього договору, не застосовується положення щодо примушення сторони, яка ухиляється від укладання основного договору, до його укладення та відшкодування збитків [4, с. 102].

Сторонами договору про надання освітніх послуг $\epsilon$ виконавець та замовник. Відповідно, виконавцем у договорі про надання освітніх послуг є заклад вищої освіти (юридична особа), а саме навчальний заклад, який надає освітні послуги. Замовником $є$ фізична особа, котра є споживачем освітньої послуги (особа, що навчатиметься), або інші особи (законні представники здобувача освіти, майбутні роботодавці) [4, с. 104]. Якщо замовником за договором про надання освітніх послуг $\epsilon$ інша фізична особа або юридична особа, у цьому випадку має місце конструкція договору на користь третьої особи, тобто того, хто навчається (ст. 636 ЦК України) [6, с. 90-91].

Щоб договір як юридичний факт породжував правові наслідки, мають бути виконані такі умови: а) наявність волі двох або більше сторін; б) певне об'єднання вольової спрямованості сторін (узгодженість волі); в) спрямованість волі сторін на досягнення певного правового результату (встановлення, зміну чи припинення прав та обов'язків). Так, заклад вищої освіти шляхом оферти пропонує майбутнім контрагентам договір про надання освітніх послуг, а також заздалегідь повідомляє відомості про ліцензію на здійснення освітньої діяльності, надає сертифікати про акредитацію відповідної спеціальності певного напряму, інформує про перелік, правила, про- цедури, строки й форму вступних випробувань, порядок подання апеляцій на їх результати тощо. Щодо відповіді на таку пропозицію акцептом вступника $\epsilon$, відповідно, особисте подання ним заяви про прийом та відповідних документів, письмове підтвердження ознайомлення з умовами вступу й навчання, а також письмова згода на участь у процедурі допуску до вищої освіти [4, с. 103].

Таким чином, для виникнення зобов'язань за договором про надання освітніх послуг необхідна наявність таких юридичних фактів: 1) конкурсу (відбору абітурієнтів); 2) укладення договору; 3 ) видання наказу про зарахування абітурієнта на навчання [9, с. 102].

Відповідно до ч. 1 ст. 638 ЦК України договір є укладеним, якщо сторони в належній формі досягли згоди 3 усіх істотних умов договору [5]. Істотні умови договору про надання освітніх послуг містяться в затвердженому Кабінетом Міністрів України Типовому договорі про надання освітніх послуг між вищим навчальним закладом та фізичною (юридичною) особою. До них відносять предмет, форму навчання, місце й строк надання освітньої послуги, обсяг навчального навантаження здобувача вищої освіти, плату за надання освітньої послуги, а також порядок здійснення розрахунків, права й обов'язки сторін, умови розірвання договору та відповідальність сторін [13].

Предметом договору про надання освітніх послуг $\epsilon$ освітні послуги. Відповідно до п. 18 ст. 1 Закону України «Про освіту» освітня послуга - це комплекс визначених законодавством, освітньою програмою та/або договором дій суб'єкта освітньої діяльності, що мають визначену вартість і спрямовані на досягнення здобувачем освіти очікуваних результатів навчання [1].

Н.В. Федорченко зазначає, що змістом послуг для набуття вищої освіти є дії навчального закладу з передання (поширення) інформації, яка відповідає вимогам (стандартам), встановленим законодавством [8, с. 212].

На думку М.П. Баб'юк, освітня послуга - це діяльність навчального закладу, спрямована на задоволення освітніх потреб здобувачів освіти та інших осіб, а саме на формування певних навичок і вмінь, необхідних для здобуття освіти $[9$, с. 73$]$.

Поняття «надання освітніх послуг» можна визначити як діяльність підприємств, установ, організацій, громадян - суб'єктів господарювання та окремих осіб (викладачів, майстрів, тренерів, вихователів, репетиторів та інших), що виконується для задоволення потреб людей (учнів, вихованців, студентів, аспірантів, докторантів та інших), роботодавців і держави, інших громадян та суб'єктів господарювання з передачі протягом певного часу або постійно сукупності знань, умінь і навичок, що визначають певний їх рівень чи ступінь, інших прав, належних навчальних закладів та яка не має матеріальної форми, не залежить від характеру результату, відбувається на платній чи безоплатній основі, що має цінову визначеність [14, с. 108]. Обсяг, зміст і характер платних освітніх послуг можуть залежати від форми навчання, структури освіти, освітньо-кваліфікаційного рівня, рівня акредитації освітнього закладу, його профілю, а також від того, який освітньо-кваліфікаційний рівень (як загалом, так і з певної спеціальності) уже має той, хто навчається $[7$, с. 6].

Поряд із предметом договору важливе значення має якість освітньої діяльності. Якість освітньої діяльності це рівень організації, забезпечення й реалізації освітнього процесу, що забезпечує здобуття особами якісної освіти та відповідає вимогам, встановленим законодавством та/або договором про надання освітніх послуг [1].

Якість освітнього процесу простежується, наприклад, в організації проведення практики у вищих навчальних закладах, у навчально-методичному забезпеченні, управлінні освітнім процесом, професійній діяльності працівників освітніх організацій. Якість результату освітньої 
діяльності - це наявність в учнів різних знань, умінь, навичок, що відповідають освітнім програмам, запитам самих учнів або інших осіб (роботодавців). Окремі елементи якості освіти представлені в законодавстві про освіту в межах інститутів ліцензування, атестації та акредитації [6, с. 92].

3 огляду на зазначене заклад вищої освіти повинен забезпечити умови для отримання якісної освіти.

Висновки. Проведений аналіз цивільно-правових аспектів укладання договору про надання освітніх послуг дає можливість зробити такі узагальнення:

- основною формою надання освітніх послуг $є$ договірна;
- під договором про надання освітніх послуг варто розуміти домовленість, згідно 3 якою одна сторона (виконавець) зобов'язується за завданням другої сторони (замовника) надати освітні послуги, що повинні відповідати державним стандартам освіти та/або домовленості сторін, а замовник зобов'язується споживати надані послуги та оплатити їх виконавцеві, якщо інше не встановлено договором чи законом;

- закріплення істотних умов договору про надання освітніх послуг у підзаконному нормативно-правовому акті, а не в законі є некоректним, тому необхідно закріпити їх у Законі України «Про вищу освіту» з огляду на його вищу юридичну силу.

\section{ЛITEPATYPA}

1. Про освіту : Закон України від 5 вересня 2017 р. № 2145-VIII / Верховна Рада України. Відомості Верховної Ради України. 2017. № 38-39. Ст. 380 .

2. Про вищу освіту : Закон України від 1 липня 2014 р. № 1556-VII / Верховна Рада України. Відомості Верховної Ради України. 2017. № 37-38. Ст. 2004.

3. Про затвердження порядків надання платних послуг державними та комунальними навчальними закладами : спільний Наказ Міністерства освіти і науки України, Міністерства економіки України, Міністерства фрінансів України від 23 липня 2010р. № 736/902/758 / Міністерство освіти і науки України, Міністерство економіки України, Міністерство фінансів України. URL: https://zakon.rada.gov.ua/laws/ show/z1196-10 (дата звернення: 10.04.2020).

4. Розгон О.В. Специфріка договору про надання освітніх послуг у вищому навчальному закладі. Науковий вісник Херсонського державного університету. Серія «Юридичні науки». 2013. № 3. Т. 1. С. 102-105.

5. ЦЦивільний кодекс України : Закон України від 16 січня 2003 р. № 435-IV / Верховна Рада України. Відомості Верховної Ради України. 2003. № 40-41. Ст. 356.

6. Голоденко І.О. Договір про надання освітніх послуг у цивільному праві України. Актуальні проблеми приватного права : матеріали Всеукраїнської науково-практичної конференції, присвяченої пам'яті Ю.С. Червоного (до 90-річчя від дня його народження), м. Одеса, 15 грудня 2017 р. / упор. та відп. ред. І.С. Канзафарова, В.М. Зубар. Одеса : Астропринт, 2017. С. 88-94.

7. Карчевський К.А. Платні освітні послуги вищих закладів освіти МВС України: цивільно-правовий аспект : автореф. дис. ... канд. юрид. наук : 12.00.03. Харків, 2001. 19 с.

8. Федоренко Н.В. Зобов'язання про надання освітніх послуг в Україні. Інновації в юридичній освіті : матер. Всеукраїнської науковопрактичної конференції до Дня науки, м. Київ, 21 травня 2015 р. Київ : Національний авіаційний університет, 2015. С. 212-215.

9. Баб'юк М.П. Цивільно-правова природа договору про надання вищим навчальним закладом освітніх послуг. Науковий вісник Ужгородського національного університету. Серія «Право». 2016. Вип. 37. Т. 1. С. 101-105.

10. Волчанская Л.М. Договор возмездного оказания образовательных услуг: правовое регулирование, понятие и содержание. Правоведение. 2002. № 3(242). С. 265-270.

11. Федорченко Н.В. Зміст зобов'язань надання послуг з вищої освіти. Підприємництво, господарство і право. 2010. № 10. С. 70-73.

12. Кохановська О.В. Цивільно-правові проблеми інформаційних відносин в Україні : автореф. дис. ... докт. юрид. наук : 12.00 .03$. Київ, 2006. 34 с.

13. Про затвердження Типового договору про надання освітніх послуг між вищим навчальним закладом та фізичною (юридичною) особою : Постанова Кабінету Міністрів України від 19 серпня 2015 р. № 634 / Кабінет Міністрів України. Офріційний вісник України. 2015. № 70. Ст. 2306.

14. Деревянко Б.В. Щодо визначення понять «надання освітніх послуг» та «надання послуг у сфері освіти». Вісник Запорізького юридичного інституту Дніпропетровського державного університету внутрішніх справ. 2011. № 4(57). С. 92-109. 